\title{
Whitefly-Transmitted Viruses in Puerto Rico
}

\section{Julio Bird and Josefina Sánchez ${ }^{1}$}

Phytopathogenic viruses transmitted by whiteflies (Homoptera-Aleyrodidae) cause diseases generally characterized by arrested development of tissues and resulting in leaf curl and other malformations. Holmes $(7)^{2}$ grouped these viruses in the family Rugaceae and recognized the single genus, Ruga, for them.

Diseases incited by whitefly-transmitted viruses occur largely in the Tropics. Whiteflies, in general, are minute and short-lived but under favorable circumstances can multiply into huge populations at extremely rapid rates. Some of the species included in the genus Bemisia are efficient vectors of viruses affecting crops of economic importance in Africa, India and other parts of the world.

Rugaceous viruses were not known to occur in Puerto Rico prior to 1956. Neither had the whitefly vector of some of the most important rugaceous viruses, Bemisia tabaci Genn., been reported in Puerto Rico. This species was found by Bird (1) in 19.56 closely associated with mosaic-affected plants of Jalropha gossypifolia (L.) Pohl. (fig. 1) and he succeeded in transmitting the causal agent of the disease via this whitefly species.

The host range of the Jalropha virus was found to include mostly euphorbiaceous species belonging to the genus Jalropha. Croton lobatus L. recently was feund susceptible to the Jatropha mosaic virus. Certain solanaceous species, including Nicotiana tabacum L., also were inoculated via this whitefly. Tobacco plants thus inoculated developed symptoms similar to those characterizing the mild form of leaf curl affecting tobacco in the Island. The Jatropha virus was shown to be different from the virus studjed by Costa and Bennett (5) affecting Euphorbia prunifolia Jacq. in Brazil.

Bird (2) reported in 19:5 that Bemisia labaci Genn. (= Bemisia inconspicua Quaintance) according to Russell (9) was the vector of the chlorosis of Silla carpinifolia I. (fig. 2) in Puerto Rico. The Sida virus was shown to be closely related to the virus studied previously on the same host by Orlando and Silberschmidt (8) in Brazil. Although unrelated to the Jatropha virus, the virus of Silla also produces what might be considered a mild form of leaf curl on tobacco.

After studying the host range of the whiteflies on Jatropha and Sida

1 Phytopathologist and Iirector of the Department of Plant Pathology and Botany, and Assistant Biologist, respectively, Agricultural Experiment Station, Mayagüez Campus, University of Puerto Rico, Río Piedras, P.R.

2 Italic numbers in parentheses refer to Literature Cited, p. 467. 
(both $B$. tabaci), Bird found that the whiteflies differed in their capacity to feed and breed on certain hosts; and also that they differed in their capacity to transmit several viruses. Based on these criteria, Bird $(1,2,3)$ distinguished two races of the whitefly in Puerto Rico: Bemisia tabaci race jatrophae and Bemisia tabaci race sidae.

Bird ( 3 ) found another virus later bearing no relationship either to Jatiopha or Sida viruses but transmitted by $B$. tabaci race sidae. This virus is called "Rhynchosia" virus, after the generic name of its primary host,

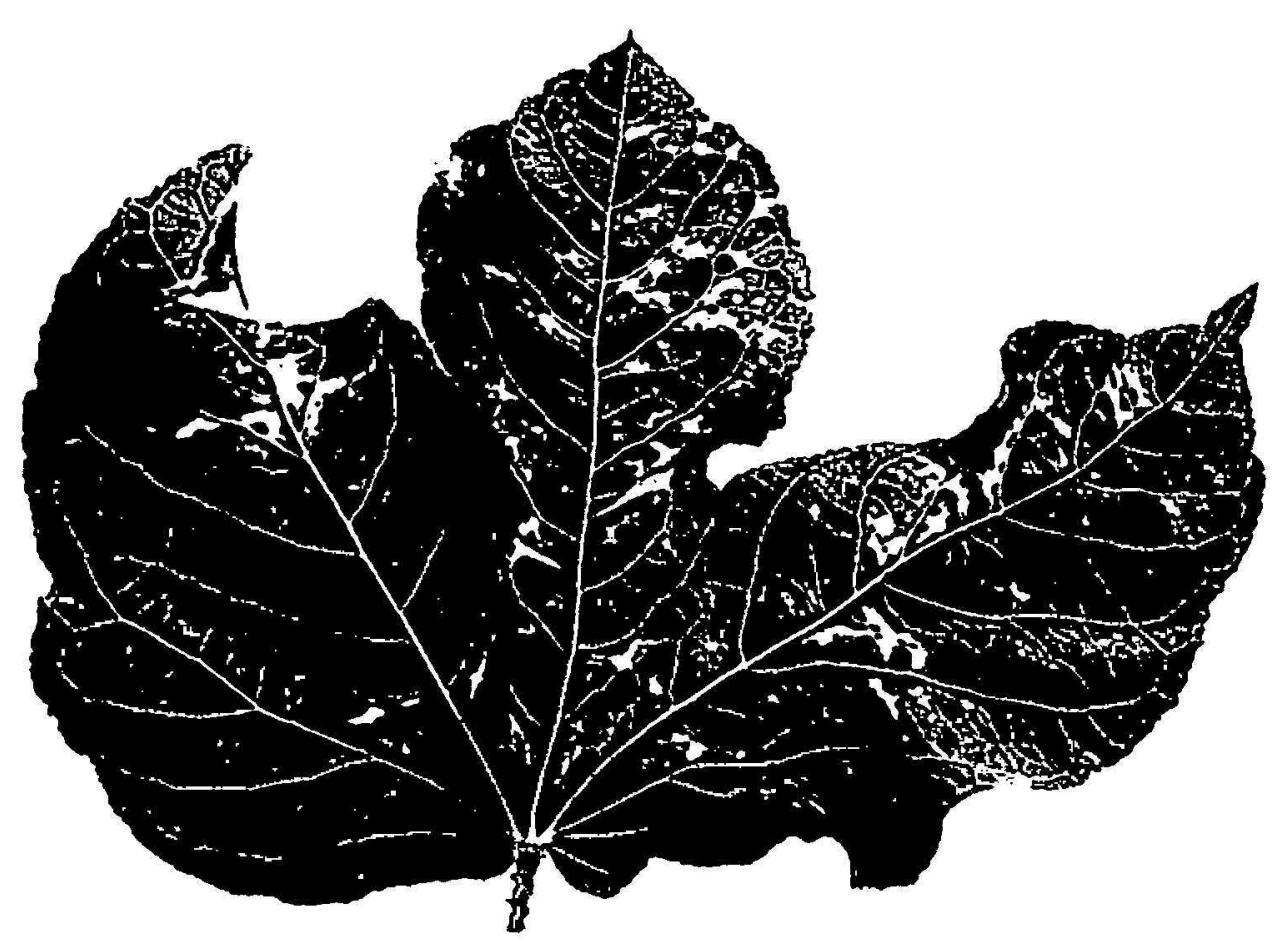

FIG. 1.-Leaf of Jatropha gossypifolia with symptoms induced by the Jatropha mosaic virus.

Rhynchosia minima (L.) DC. Typically, it is a legume virus. Interestingly enough, it was found to produce the severe form of leaf curl on all leading tobacco varieties grown in Puerto Rico. The symptoms (stunting, enations and severe curling) produced by this virus on tobacco are indistinguishable from those which typify the "Kroepoek" and leaf curl diseases of tobacco in Sumatra, Africa, and India (fig. 3). This virus has an extensive host range in Puerto Rico and produces mosaic diseases of Abelmoschus esculentus L., Cajanus indicus Spreng. and certain other plant species including beans, Phaseolus lathyroides L. and Canavalia species. Moreover, it causes an ephemeral mosaic on cotton when inoculation is effected during the cotyle- 
don stage. The host range of the Rhynchosia virus, and the general symptomatology it induces on certain species, indicates a relationship to the yellow mosaic virus of Phaseolus lunatus L., studied by Capoor and Varma (4) in India, and to the yellow mosaic of Phaseolus longepedunculatus Mart., investigated by Flores and Silbersehmidt (6) in Brazil.

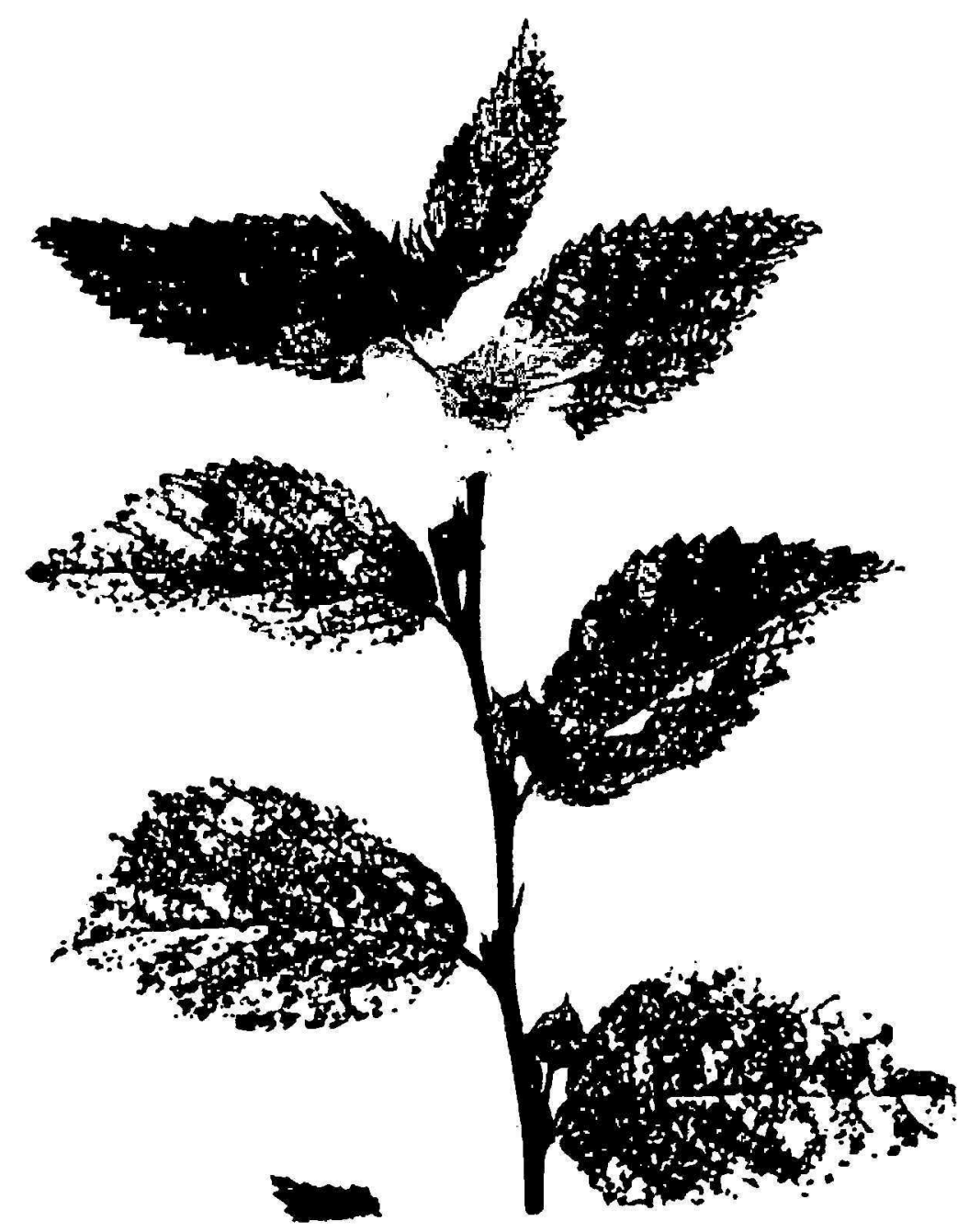

FIG. 2.-Characteristic symptoms of the mostic of Sida carpinifolia (host-Sida carpinifolia).

In 1961 Bird found B. tabaci race sidae capable of spreading a fourth, distinct virus causing mosaic of Ipomoea quinquefolia $\mathrm{L}$. This particular agent produces a vivid yellow mottle on leaves of $I$. quinquefolia (fig. 4) and also affects several wild species of Ipomoea in Puerto Rico. It also (auses a rather severe form of leaf curl on tobacro. Infected tobacco plants, however, fail to develop outgrowths and enations. This characteristic 
clearly distinguishes Ipomoea virus from the causal agent of the Rhynchosia mosaic. To date, however, the writers have been unable to transmit the Ipomoea virus to Ipomoea balatas $\mathrm{L}$.

It was determined more recently that the golden-yellow mosaic (fig. $\overline{5}$ ) of Jacquemontia tamnifolia Griseb., another convolvulaceous weed, is spread by the sidae race of $B$. tabaci. The host range of this new virus is rather limited as evidenced by the fact that heretofore only two plant species, besides the primary host, have been successfully inoculated via the whitefly vector.

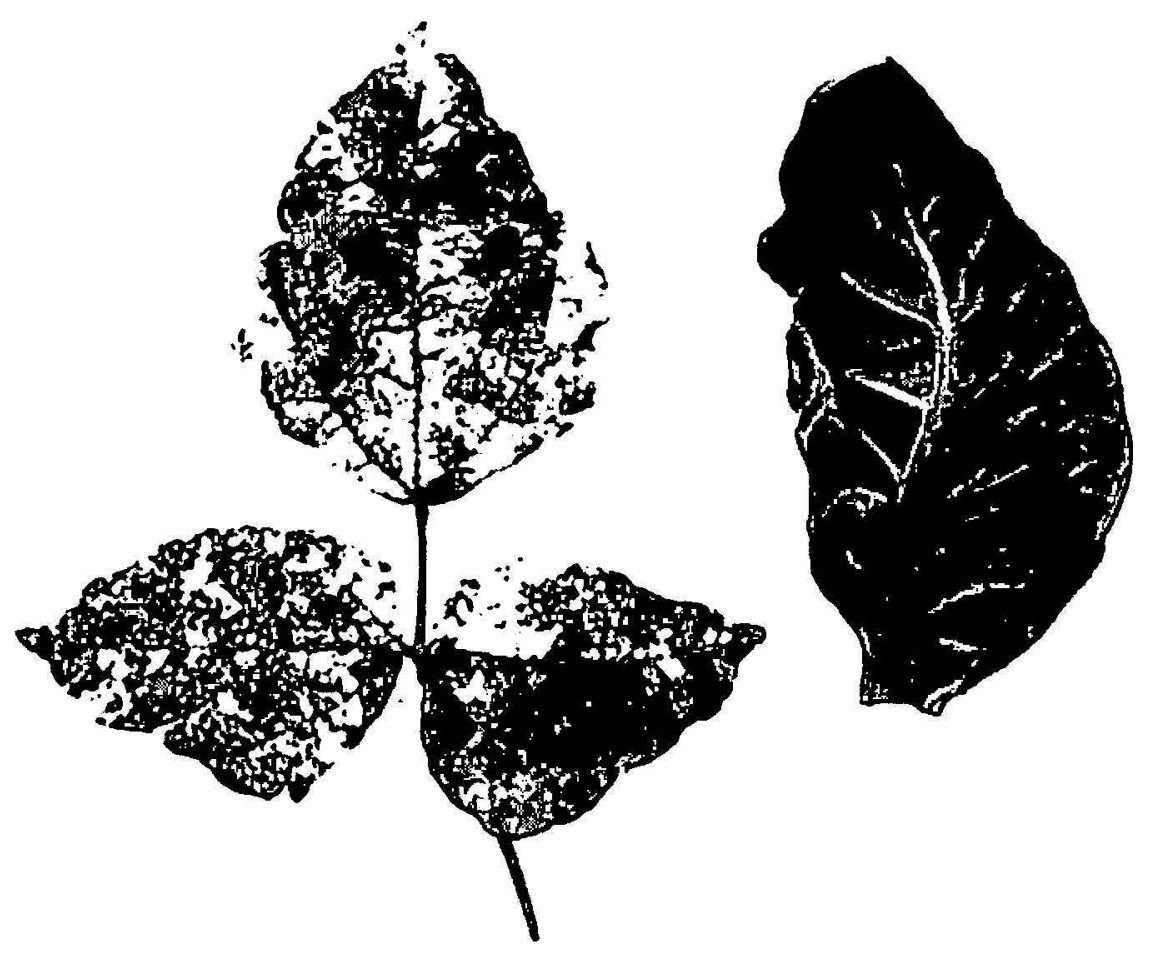

FIG. 3.-Leaves of Rhynehosia minima (left) and . Virotiana tabacum (right) affected by the mosaic virus of Rhynchosia minima.

Five distinct rugaceous viruses have been identified thus far in Puerto Rico. Three were previously undescribed. One apparently is related to the agent that causes leaf curl of tobacco in India.

The Puerto Rican counterpart of the Indian leaf curl virus is a virulent entity and should receive more attention. It has an extensive host range. It has a well distributed and abundant primary host which almost always is afferted by mositic and coknized by viruliferous whit eflies. Unquestionably, R. minima is the ideal host; it thrives well even when affected by the virus. It supports large colonies of the whit efly without sustaining severe damage. 
Occasionally, the Rhynchosia virus spreads via its vector causing light to severe damage in tobacco fields. It also invades pigeon pea plantings, particularly in the dry areas of the southern coast of the Island.

A seemingly new yellow mosaic destroyed a large bean planting of the

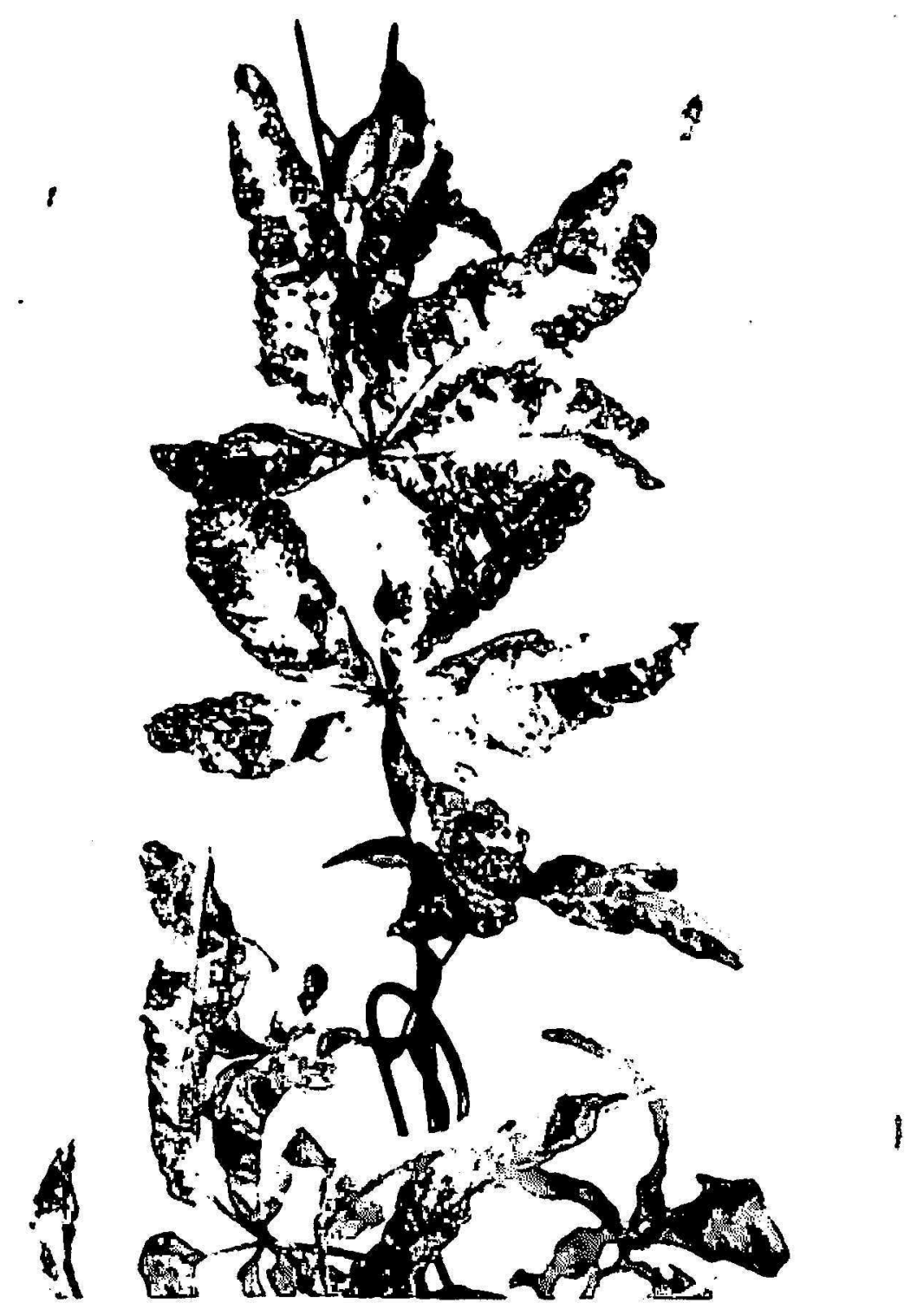

FıG. 4.--Mosaic-alfected leaves of Ipomoea quinquefolia (causal agent-mosaic virus of 7 pomoea quinquefolia).

variety Harvester a few months ago in the municipality of Isabela. As a result of host range and vector studies, it was clearly demonstrated that the causal agent was none other than the Rhynchosia mosaic virus being spread by $B$. labaci race sillae.

It is probable that additional whitefly-transmitted viruses will be discovered in Puerto Rico. It also seems likely that some of those already 
known will acquire greater importance as additional acreage is devoted to susceptible crops.

\section{SUMMARY}

The viruses transmitted by the Puerto Rican whitefly (Bemisia tabaci Genn.), their vectors, and their main hosts are discussed in the present

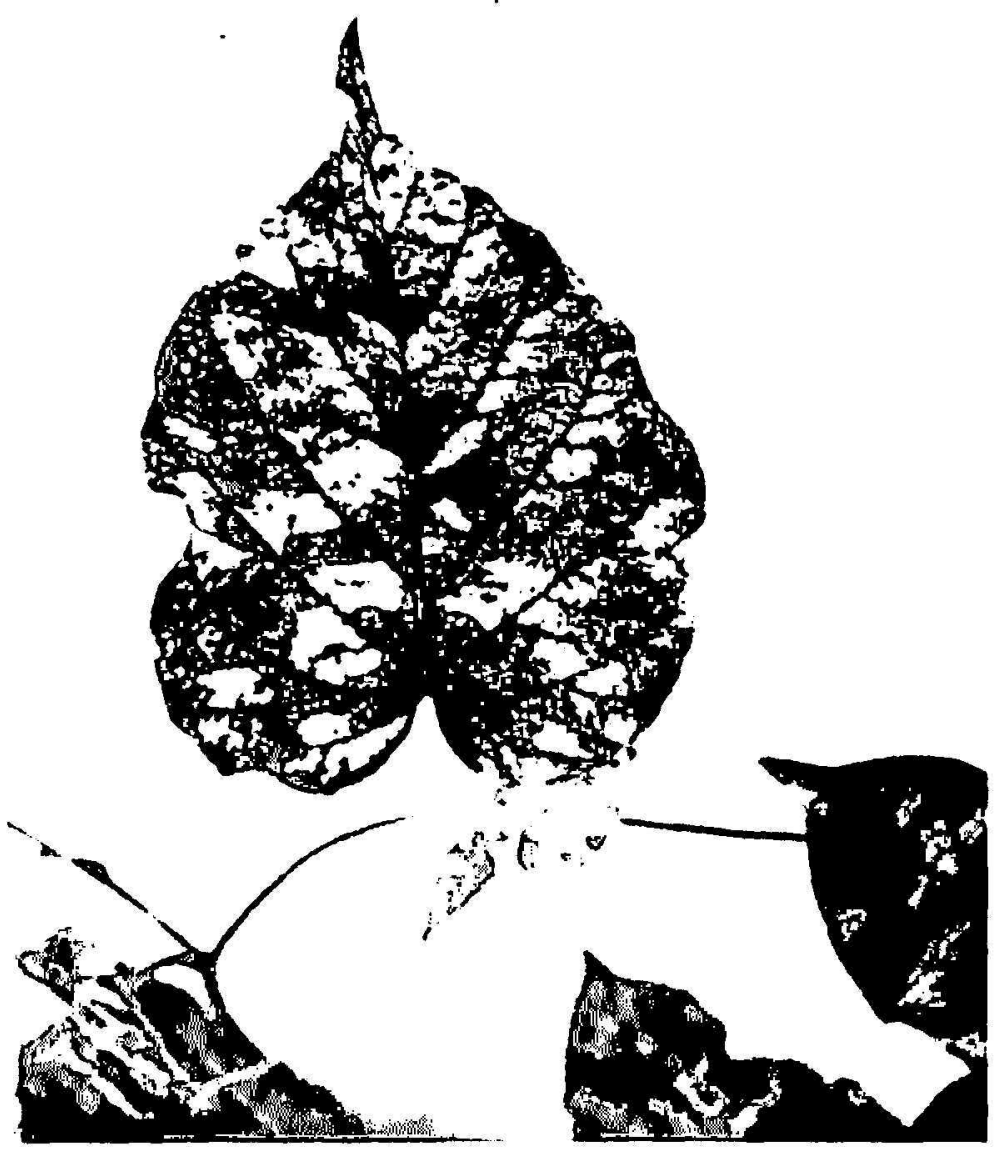

Fic. 5.-Lenf of Jacquemontia tamnifolia atfected by the Jacquemontia mosaic virus.

paper. The possible relationships between some of these viruses and certain forelgn rugareous viruses also are discussed. It seems that the Rhynchosia mosaic (Puerto Rico), the yellow mosaic of Phaseolus lunatus I. (India) and the yellow mosaic of Phaseolus longepedunculatus MIart. (Brazil) are related diseases. The Puerto Rican mosaic of Silla carpinifolia also seems related to the Brazilian chlorosis of Malvaceae. Five seemingly different rugaceous viruses have been studied in Puerto Rico.

\section{RESUMEN}

En este artículo se enumeran los virus transmitidos en Puerto Rico por la mosca blanca Bemisia tabaci Genn. Además se mencionan sus vectores y 
sus principales hospedadoras. También se discute la relación que pudiera existir entre algunos de estos virus y ciertos virus rugáceos que ocurren en otros países. Tal parece que el mosaico de Rhynchosia minima está relacionado con el mosaico amarillo de Phaseolus lunatus (India) y con el mosaico amarillo de Phaseolus longepedunculatus (Brasil). El mosaico de Sida carpinifolia estudiado en Puerto Rico es muy similar al que ocurre en Brasil en la misma especie. Hasta la fecha se han estudiado en Puerto Rico cinco virus rugáceos. Estos son aparentemente distintos.

\section{LITERA'TURE CITED}

1. Bird, J., A whitefly transmitted mosaic of Jatropha gossypifolia, Agr. Exp. Sta. Univ. P.R., Tech. Paper 22, 1957.

2. Bird, J., Infections chlorosis of Sida carpinifolia in Puerto Rico, Agr. Exp. Sta., Univ. P.R., Tech. Paper 2i, 1958.

3. Bird, J., A whitefly transmitted mosnic of Rhynrhosia minima J)C. and its relation to tobaceo leaf curl and other virus disenses of plants in Puerto Rico, Proc. Carib. Region Amer. Soc. Horl. Sri. 5: 19)(i2.

4. Capoor, S. P. and Varma, P. M., Yellow mosaic of Phascolus lunalus I., C'urr. Sci. 17: 152-3, 1948.

5. Costa, A. S. and Bennett, C. W., Whitefly-transmitted mosaic of Euphorbia prunifolia, Phytopathology 40: 266-83, 1950.

6. Flores, E. and Silberschmidt, K., Studies on a new virus disease of Phascolus longepedunculatus, Anais da Arademia Brasileira de ('iencias 38: 327-34, 1966.

7. Ilolmes, F. O., The Filterable Viruses, The Williams \& Wilkins Co., Baltimore, Maryland, 1948.

8. Orlando, II. and Silberschmidt, K., listudos sobre a disseminacao natural do virus da "clorose infecciosa" das malvaceas (Abutilon virus I Baur) e sua relacao com o inseto-vetor "Bemisia tabaci ((ienu.)" (IIomoptera-Aleyrodidae), Arquivos do Instituto Biologico 17: 1-36, 1946.

9. Russell, L. M., Synonyms of Bemisia tabaci ((iennadius) (Homoptern-Aleyrodidae), Bull. Brooklyn Ent. Soc. 52: 122-3, 1957. 